\title{
ORNAMEN DAN NILAI-NILAI KARAKTER CERITA PAÑCATANTRA PADA RELIEF CANDI MENDUT DAN CANDI SOJIWAN
}

\author{
Waluyo \\ Sekolah Tinggi Agama Buddha Negeri Sriwijaya \\ waluyo.stabn.sriwijaya@gmail.com
}

\begin{abstract}
ABSTRAK
Penelitian ini didasarkan pada cerita bertema pañcatantra di Candi Mendut dan Candi Sojiwan yang mengandung nilai moral luhur dalam membentuk karakter seseorang, namun belum dimanfaatkan secara optimal, serta belum adanya penjabaran komprehensif persamaan dan perbedaannya pada kedua candi, baik pada ornamen dan analisis reliefnya maupun karakter yang ada. Penelitian ini bertujuan untuk mendeskripsikan ornamen dan nilai-nilai karakter cerita pañcatantra yang terdapat di Candi Mendut dan Candi Sojiwan.

Penelitian ini menggunakan paradigma kualitatif dengan metode penelitian arkeologi yang mendasarkan pada analisis ikonografi. Relief bertema pañcatantra dilakukan analisis ikonografi dari segi narasi, bentuk, morfologi, teknologi, dan kontekstual. Data bersumber dari Candi Mendut dan Candi Sojiwan yang terpahat banyak relief bertema pañcatantra yang mengandung nilai-nilai karakter. Keabsahan data ditempuh melalui peningkatan ketekunan, diskusi dengan sejawat dan ahli, triangulasi, di samping proses dependability, transferability, dan confirmability. Analisis data menggunakan analisis relief sebagai bagian dari analisis ikonografi.

Hasil penelitian menunjukkan bahwa: (a) relief cerita fabel bertema pañcatantra yang terpahat pada Candi Mendut dan Candi Sojiwan yaitu ñGaruda dan Penyuò, ñBuaya dan Keraò, ñGajah dan Tikus Pengeratò, ñ́Kepiting dan Bangauò, ñßurung Berkepala Duaò, dan ñSerigala dan Lembuò; sedangkan cerita yang hanya terdapat pada Candi Mendut yaitu ñUlar dan Luwakò, ñPenyu dan Angsaò, ñSeekor Keraò, ñ́Brahmana, Ular, dan Kepitingò, ñRusa, Macan, dan Keraò, ñUlar dan Manusia Terbangò, ñKera Pemarahò, ñMacan, Kera, dan Kambingò, ñDua Rusaò, dan ñKucing dan Tiga Tikusò; serta cerita yang hanya terdapat di Candi Sojiwan yaitu ñ̃inga dan Manusiaò, ñSerigala dan Manusiaò, ñAnjing dan Manusiaò, dan ñGajah dan Kambingò, (b) persamaan ornamen relief pañcatantra pada Candi Mendut dan Candi Sojiwan mengambil bentuk monoscenic narratives, bentuk continuous narratives pada Candi Mendut; sebagian besar berbentuk empat persegi panjang, ada juga bentuk segitiga dan tak beraturan pada Candi Mendut; sedangkan pada analisis morfologi figur yang dipahatkan sebagian besar naturalis, pada Candi Sojiwan ditemukan tidak naturalis berupa garuda, hiasan kerang, dan kinnara; ukuran relief pada Candi Mendut bervariasi, pada Candi Sojiwan berukuran sama; pada kedua candi memiliki ukuran figur tokoh sentral yang diapit oleh hiasan flora dan atau fauna; dari segi teknologi, kedua candi termasuk kategori haut relief; analisis kontekstual kedua candi berbeda atas ditemukannya gana unik dan spesifik berupa gajah, singa, dan manusia menunggang singa di Candi Sojiwan; persamaannya yaitu terdapat makara dan gana dengan karakter yang sedikit berbeda; (c) nilai-nilai karakter cerita pañcatantra pada Candi Mendut dan Candi Sojiwan yang bernilai
\end{abstract}


positif yaitu tanggung jawab, strategi, pengorbanan, pertolongan, kebersamaan, suka cita, usaha keras, kerja bertahap, belas kasih, balas budi, kebijaksanaan, persahabatan, saling menolong, persaudaraan, kecerdikan, berterima kasih, pemahaman sebab akibat, kesetiaan, kejujuran, kesabaran, tepat waktu, perjuangan, kewaspadaan, empati, dan siap menghadapi tantangan; sedangkan nilai-nilai negatif yang muncul di antaranya permusuhan, tipu daya, balas dendam, lupa diri, kesombongan, keras kepala, serakah, rakus, rencana jahat, pembunuhan, tipu muslihat, kebodohan, kekalahan, suka mengejek, kemarahan, mengharapkan sesuatu yang tidak mungkin, bersama dalam kejahatan, kepurapuraan, keinginan lebih, iri hati, keinginan salah, dan menyia-nyiakan kesempatan.

Kata kunci: Candi Mendut, Candi Sojiwan, pañcatantra, ornamen, relief.

\section{PENDAHULUAN}

Kebudayaan dan kearifan lokal menjadi dasar dalam pemilihan sumber belajar yang powerful dalam merencanakan pembelajaran di kelas. Unsur-unsur budaya daerah dapat dicari makna filosofis maupun metodis untuk membangun cara dan metode pembelajaran yang kontekstual. Pembelajaran kontekstual dapat memotivasi peserta didik untuk memahami materi pembelajaran dengan mengaitkan pada sumber belajar atau pengalaman yang ditemui dalam dunia yang dekat dengan kesehariannya. Namun demikian, sumber belajar yang berbasis kearifan lokal masih sedikit dimanfaatkan oleh penyelenggara pendidikan untuk dijadikan sebagai sarana pencapaian tujuan pembelajaran. Relief pañcatantra yang terpahat pada dinding candi dapat dipandang sebagai kearifan lokal yang mengandung cerita bermakna mendalam untuk penguatan pendidikan karakter.

Cerita pañcatantra yang terpahat di Candi Mendut dan Candi Sojiwan memiliki pesan moral yang dapat digunakan sebagai sumber belajar dalam pendidikan karakter. Cerita pañcatantra mengandung nilai-nilai kehidupan yang masih relevan dengan pendidikan karakter di masa kini. Cerita pañcatantra di Candi Mendut dan Candi Sojiwan relatif sama dalam pengambilan bentuk yang banyak menampilkan cerita hewan, namun juga ada beberapa perbedaan cerita yang dipahatkan. Perbedaan tampak pada jenis relief, bentuk panil relief, dan teknik analisis. Unsur nilai-nilai pesan moral yang disampaikan, baik dari persamaan maupun perbedaan cerita pañcatantra dari kedua candi tersebut 
sebagai sumber belajar pendidikan karakter perlu dideskripsikan secara komprehensif.

Cerita pañcatantra yang berasal dari India Kuno menyebar ke seluruh dunia secara mudah dan terjaga hingga kini dengan membawa pesan moral melalui media yang efektif dan efisien, di samping memiliki cita rasa bernilai artistik tinggi. Penerjemahan cerita pañcatantra ke dalam media yang sesuai dengan konteks budaya dan masyarakat melalui berbagai media membedakan pemaknaan masyarakatnya sesuai dengan latar belakang dan karakteristik budaya setempat. Namun demikian, persamaan penerjemahan makna juga terdapat pada penggunaan media dan penokohan relief yang dipahatkan. Hal ini juga tersirat pada relief pañcatantra yang terdapat pada Candi Mendut dan Candi Sojiwan, namun belum ada analisis yang cukup komprehensif tentang persamaan dan perbedaan tersebut, baik dari segi ornamen, cerita, maupun pemaknaan pesan cerita yang terkandung di dalamnya. Perbandingan mengenai persamaan dan perbedaan pada relief kedua candi diperlukan untuk mengetahui karakteristik masing-masing agar dapat digunakan pemanfaatannya sebagai sumber belajar kontekstual sesuai dengan kearifan lokal.

Hasil deskripsi penggambaran perbandingan cerita pañcatantra yang terdapat pada Candi Mendut dan Candi Sojiwan diharapkan memberikan manfaat besar dalam mendukung program Gerakan Penguatan Pendidikan Karakter yang dicanangkan oleh Pemerintah. Cerita pañcatantra yang terpahat pada relief Candi Mendut dan Candi Sojiwan sebagai hasil kebudayaan dan kearifan lokal memiliki potensi besar untuk dijadikan sumber belajar dalam pendidikan karakter. Sumber belajar dengan memanfaatkan kearifan lokal memiliki signifikansi besar sebagai kekuatan yang mengubah dan membekali peserta didik dalam menghadapi degradasi moral, etika, dan budi pekerti. Di samping itu, dari segi arkeologi pada situs keagamaan, manfaat kajian ini berdampak pada pemahaman analisis relief yang cukup komprehensif tentang cerita pañcatantra yang banyak dijumpai di beberapa candi di Indonesia, baik dari sudut jenis, bentuk, morfologi, teknologi, maupun kontekstual.

Penelitian ini bertujuan untuk mengetahui persamaan dan perbedaan ornamen dan nilai-nilai karakter cerita pañcatantra yang terdapat di Candi 
Mendut dan Candi Sojiwan. Tujuan ini dijadikan acuan untuk menghasilkan kesimpulan yang mengarah pada jumlah relief cerita pañcatantra yang terdapat di Candi Mendut dan Candi Sojiwan, persamaan ornamen dan karakter cerita pañcatantra yang terdapat di kedua candi, serta nilai-nilai karakter yang muncul dari cerita pañcatantra yang terdapat di Candi Mendut dan Candi Sojiwan.

Menurut Helen G. Douglas (Muchlas Samani \& Hariyanto, 2012: 41) bahwa character isn't inherited, one builds its daily by the way one thinks and acts, thought by thought, action by action. Karakter dibangun secara berkesinambungan secara periodik hari ke hari, melalui pemikiran dan perbuatan, pikiran demi pikiran, dan tindakan demi tindakan. Pendidikan karakter dirancang untuk membiasakan penanaman dan penumbuhan karakter bernilai baik agar terinternalisasi dalam pribadi setiap orang. Pengembangan karakter menjadi tanggung jawab semua pihak yang ditempuh dengan berbagai cara, media, strategi, jenjang pendidikan, bentuk pendidikan, maupun melalui kelompokkelompok masyarakat tertentu. Karakter setiap individu dipandang sebagai kepribadian yang menjadi sifat mulai yang terwujud dari pikiran, ucapan, dan perbuatan seseorang. Menurut pandangan Buddhis, nilai-nilai karakter sejalan dengan kebajikan-kebajikan mulia yang diperjuangkan seseorang dalam mencapai kesempurnaan sebagai pribadi luhur. Kebajikan mulia dilakukan dalam rangka menjaga keharmonisan masyarakat sebagai upaya realisasi pribadi berkarakter. Kebajikan-kebajikan mulia yang harus dilaksanakan sebagai karakter luhur yaitu dāna (kemurahan hati), sīla (kebajikan, moralitas), nekkhamma (melepaskan keduniawian), pañ̃̄a (kebijaksanaan), viriya (tekun, semangat, usaha), khanti (kesabaran, toleransi, penerimaan, daya tahan), sacca (kebenaran, kejujuran), adhițthāna (tekad, resolusi), mettā (cinta kasih), dan upekkhā (ketenangseimbangan) (Mingun, 2009: 76).

Pañcatantra terdiri dari dua kata, yaitu pañca yang berarti lima dan tantra yang bermakna ajaran untuk berperilaku yang terdiri dari lima hal yaitu percaya diri atau keteguhan pikiran, kemakmuran, kesungguhan berusaha, persahabatan, dan pengetahuan (Shivkumar, 2015: 3). Tema-tema cerita dalam pañcatantra mencerminkan karakter dan sikap afektif yang berguna bagi peserta didik, baik untuk sukses belajar maupun bekal dalam menjalani kehidupan di masa 
mendatang. Teks awal pañcatantra ditulis oleh cendekiawan Hindu bernama Vishnu Sharma sekitar tahun 200 Sebelum Masehi yang sekarang telah berkembang ke Persia, Arab, Yunani, bahkan Eropa (Pai, 1981: i). Cerita pañcatantra bertemakan nilai-nilai karakter yang terdapat pada kehidupan masyarakat. Menurut Ryder (1925: 8-11) pañcatantra terdiri dari lima buku dengan judul masing-masing mengenai tema dari cerita-cerita yang terkandung di dalamnya, yaitu the loss of friends, the winning of friends, crows and owls, loss of gains, dan ill-considered action. Setiap buku bukanlah merupakan kelanjutan dari buku lainnya dan bukan buku yang berisi cerita bersambung. Pañcatantra di Indonesia dikenal dengan cerita Tantri, terutama di Jawa sebagai penghormatan kepada gadis bernama Dewi Tantri dan di Bali dari gadis bernama Ni Diah Tantri; di mana gadis tersebut bertugas menceritakan satu kisah kepada seorang raja setiap malam sepanjang periode tertentu hingga raja menjadi terpesona atas kisahkisah yang disampaikan (Made Taro, 2015: vii). Cerita pañcatantra banyak terdapat di relief-relief candi di Indonesia, di antaranya Candi Mendut dan Candi Sojiwan.

Candi Mendut dalam Prasasti Karangtengah dikenal dengan nama venuvanamandira yang berarti sebuah candi yang berada di tengah-tengah hutan bambu (Soeharsono, 1969: 26). Relief cerita yang dipahatkan di Candi Mendut berasal dari Kitab Jataka, Panchatantra, dan Tantri (Kaelan, 1959: 15). Candi Mendut memiliki signifikansi dengan Candi Plaosan sebagai candi Buddhis yang memiliki persamaan dan perbedaan dalam hal cerita yang terpahat pada reliefnya. Menurut Blom (1935) dalam Lailly Prihatiningtyas (2017: 120) nama Sojiwan berasal dari frasa Sanskerta reksajivan, yang berarti pertahanan hidup. Analisis relief merupakan salah satu bagian dari analisis ikonografi pada metode penelitian arkeologi, selain analisis ikonografi klasik dan analisis arca megalitik. Relief merupakan suatu bentuk dari hiasan yang terdapat dalam karya arsitektur berupa bangunan candi, petirtaan, gua-gua, punden berundak, pintu gerbang, dan lainnya (Dewan Redaksi Pusat Penelitian dan Pengembangan Arkeologi Nasional, 2008: 108). Narasi yang dipahatkan dalam bentuk relief meliputi: monoscenic narratives, continuous narratives, sequential narratives, synoptic narratives, dan conflated narratives (Dehejia, 1997: 10-32). 


\section{METODE}

Penelitian ini merupakan penelitian kualitatif dengan menggunakan metode penelitian arkeologi yang mendasarkan pada analisis ikonografi. Analisis ikonografi merinci ciri-ciri suatu benda yang menggambarkan tokoh dewa atau orang suci, atau simbol-simbol keagamaan tertentu dalam bentuk lukisan, relief, mosaik, arca, atau benda lainnya (Dewan Redaksi Pusat Penelitian dan Pengembangan Arkeologi Nasional, 2008: 101). Penelitian ini juga menggunakan interaksionisme simbolis sebagai aliran teori yang mendasarinya. Interaksionisme simbolis menekankan pertanyaan pada kumpulan simbol dan pemahaman umum apa yang muncul dan memberikan makna pada interaksi antarmanusia (Dédé Oetomo, 2013: 178). Di samping mendasarkan pada teori interaksionisme, penelitian ini juga menggunakan segitiga makna (triangle of meaning: sign, object, interpretant) dari Charles Sanders Peirce. Penelitian ini mengambil tempat pada monumen tak bergerak Candi Mendut, Desa Mendut, Kecamatan Mungkid, Kabupaten Magelang dan Candi Sojiwan, Desa Kebondalem Kidul, Kecamatan Prambanan, Kabupaten Klaten. Pada kedua candi tersebut terdapat relief cerita pañcatantra yang mengandung pesan moral yang sesuai untuk mendukung upaya Pemerintah dalam Gerakan Penguatan Pendidikan Karakter.

Subjek penelitian adalah seorang yang mengetahui keberadaan relief cerita pañcatantra yang terdapat di Candi Mendut dan Candi Sojiwan. Informasi digali tidak saja berupa informasi verbal dari subjek penelitian tetapi juga dikonfirmasi dengan dokumen pendukung yang ada hubungannya dengan cerita-cerita yang terpahat pada dinding kedua candi. Objek penelitian adalah cerita pañcatantra yang terpahat pada dinding Candi Mendut dan Candi Sojiwan. Penelitian ini hendak mengkaji perbandingan cerita pañcatantra yang ada di Candi Mendut dan Candi Sojiwan dalam hubungannya dengan sumber belajar pendidikan karakter dan pedoman menjalani kehidupan.

Data penelitian ini merupakan informasi deskriptif berupa relief bertema pañcatantra yang terpahat pada Candi Mendut dan Candi Sojiwan. Deskripsi mengenai cerita-cerita yang dipahatkan berasal dari dokumen buku-buku tentang cerita pañcatantra maupun yang berkembang di masyarakat. Data bersumber dari 
relief yang terpahat pada dinding Candi Mendut dan Candi Sojiwan yang diobservasi dan didokumentasi.

Berdasarkan kepentingan menangkap makna secara tepat, cermat, rinci, dan komprehensif, pengumpulan data dalam penelitian ini dilakukan melalui dokumentasi dan observasi. Kedua teknik pengumpulan data digunakan untuk saling melengkapi satu sama lain, di samping sebagai salah satu cara menjaga kredibilitas data. Dokumentasi digunakan untuk mengumpulkan data dan informasi mengenai relief cerita pañcatantra yang terdapat pada dinding Candi Mendut dan Candi Sojiwan.

Cara yang digunakan untuk memeriksa keabsahan data dalam penelitian ini adalah dengan menguji kredibilitas data, yang meliputi perpanjangan pengamatan, peningkatan ketekunan, triangulasi, diskusi dengan teman, dan analisis kasus negatif; transferability; dependability; dan confirmability (Sugiyono, 2007: 121). Penelitian ini berusaha memenuhi semua keabsahan data untuk menjamin validitas dan reliabilitas data.

Penelitian ini menggunakan teknik analisis relief untuk menggambarkan proses penelitian yang meliputi analisis morfologi, teknologi, dan kontekstual (Dewan Redaksi Pusat Penelitian dan Pengembangan Arkeologi Nasional, 2008: 113-114). Analisis morfologi mendeskripsikan relief berdasarkan figur yang dipahatkan, perbedaan tokoh pria, wanita, bangsawan, putri, raksasa, dewa, dan makhluk lainnya, flora, dan fauna pada tiap panil. Analisis teknologi menjelaskan teknik pahatan, media, langgam atau gaya relief. Analisis kontekstual berupaya menghubungkan keterkaitan antara relief dengan artefak lainnya pada tempat relief dipahatkan.

Hasil analisis relief digunakan untuk proses selanjutnya dalam pemaknaan nilai-nilai karakter yang mendasarkan pada model Spradley dengan tahapan sebagai berikut: (1) analisis domain, (2) analisis taksonomi, (3) analisis komponensial, dan (4) analisis tema budaya (Djamal, 2015: 149).

\section{HASIL DAN PEMBAHASAN}

Nilai-nilai karakter yang terpahat pada relief pañcatantra di Candi Mendut dan Candi Sojiwan memiliki tema sentral yang sama dengan mengambil cerita 
fabel untuk menggambarkan jalannya kisah. Sinopsis masing-masing cerita diperoleh dari berbagai sumber, baik dokumen maupun wawancara singkat dari informan yang sering menggunakan kisah pañcatantra sebagai media pengajaran moral. Eksistensi relief pañcatantra di kedua candi diperoleh berdasarkan observasi terstruktur pada beberapa periode waktu untuk merinci keseluruhan data. Analisis relief dikelompokkan dalam berbagai aspek yaitu narasi cerita, morfologi, teknologi, dan kontekstual. Analisis narasi cerita menemukan dua kategori yaitu monoscenic narratives dan continuous narratives. Analisis morfologi yang terdiri dari figur, pakaian, perhiasan, bentuk, ukuran, maupun hiasan dekoratif menemukan sejumlah persamaan dan perbedaan yang cukup signifikan. Analisis teknologi dan kontekstual menemukan persamaan yang nyata, di samping sejumlah kecil perbedaan pada penggambaran figur tidak naturalis dan penempatan gana berupa gajah dan manusia menunggang singa pada Candi Sojiwan. Nilai-nilai karakter sebagai pesan moral yang disampaikan pada cerita relief bertema pañcatantra pada Candi Mendut dan Candi Sojiwan memiliki persamaan dalam memberikan pelajaran moral yang digunakan sebagai pedoman menjalani kehidupan. Keseluruhan temuan sebagai data penelitian dapat dilihat pada tabel-tabel berikut.

Tabel 1

Nilai-Nilai Karakter Relief Bertema Pañcatantra di Candi Mendut dan Candi Sojiwan

\begin{tabular}{|c|c|c|c|}
\hline & $\begin{array}{l}\text { Judul Cerita } \\
\text { Ular dan Luwak }\end{array}$ & \multicolumn{2}{|l|}{ Nilai Karakter } \\
\hline Mendut & Ular dan Luwak & $\begin{array}{l}\text { - Tanggung jawab } \\
\text { - Strategi } \\
\text { - Pengorbanan }\end{array}$ & $\begin{array}{l}\text { - Permusuhan } \\
\text { - Tipu daya } \\
\text { - Balas dendam }\end{array}$ \\
\hline & Penyu dan Angsa & $\begin{array}{l}\text { - Pertolongan } \\
\text { - Kebersamaan } \\
\text { - Suka cita }\end{array}$ & $\begin{array}{l}\text { - Lupa diri } \\
\text { - Kesombongan } \\
\text { - Keras kepala }\end{array}$ \\
\hline & Seekor Kera & $\begin{array}{l}\text { - Usaha keras } \\
\text { - Kerja bertahap }\end{array}$ & $\begin{array}{l}\text { - Serakah } \\
\text { - Rakus }\end{array}$ \\
\hline & Brahmana, Ular, dan Kepiting & $\begin{array}{l}\text { - Belas kasih } \\
\text { - Balas budi } \\
\text { - Kebijaksanaan }\end{array}$ & $\begin{array}{l}\text { - Rencana jahat } \\
\text { - Pembunuhan } \\
\text { - Tipu muslihat }\end{array}$ \\
\hline & Penyu dan Garuda & $\begin{array}{l}\text { - Persaudaraan } \\
\text { - Kecerdikan } \\
\text { - Kebersamaan }\end{array}$ & $\begin{array}{l}\text { - Tipu muslihat } \\
\text { - Kebodohan } \\
\text { - Kekalahan }\end{array}$ \\
\hline & Ular dan Manusia Terbang & $\begin{array}{l}\text { - Balas budi } \\
\text { - Tanggung jawab } \\
\text { - Berterima kasih }\end{array}$ & \\
\hline & Kera Pemarah & $\begin{array}{l}\text { - Pemahaman } \\
\text { sebab akibat }\end{array}$ & - Suka mengejek \\
\hline
\end{tabular}




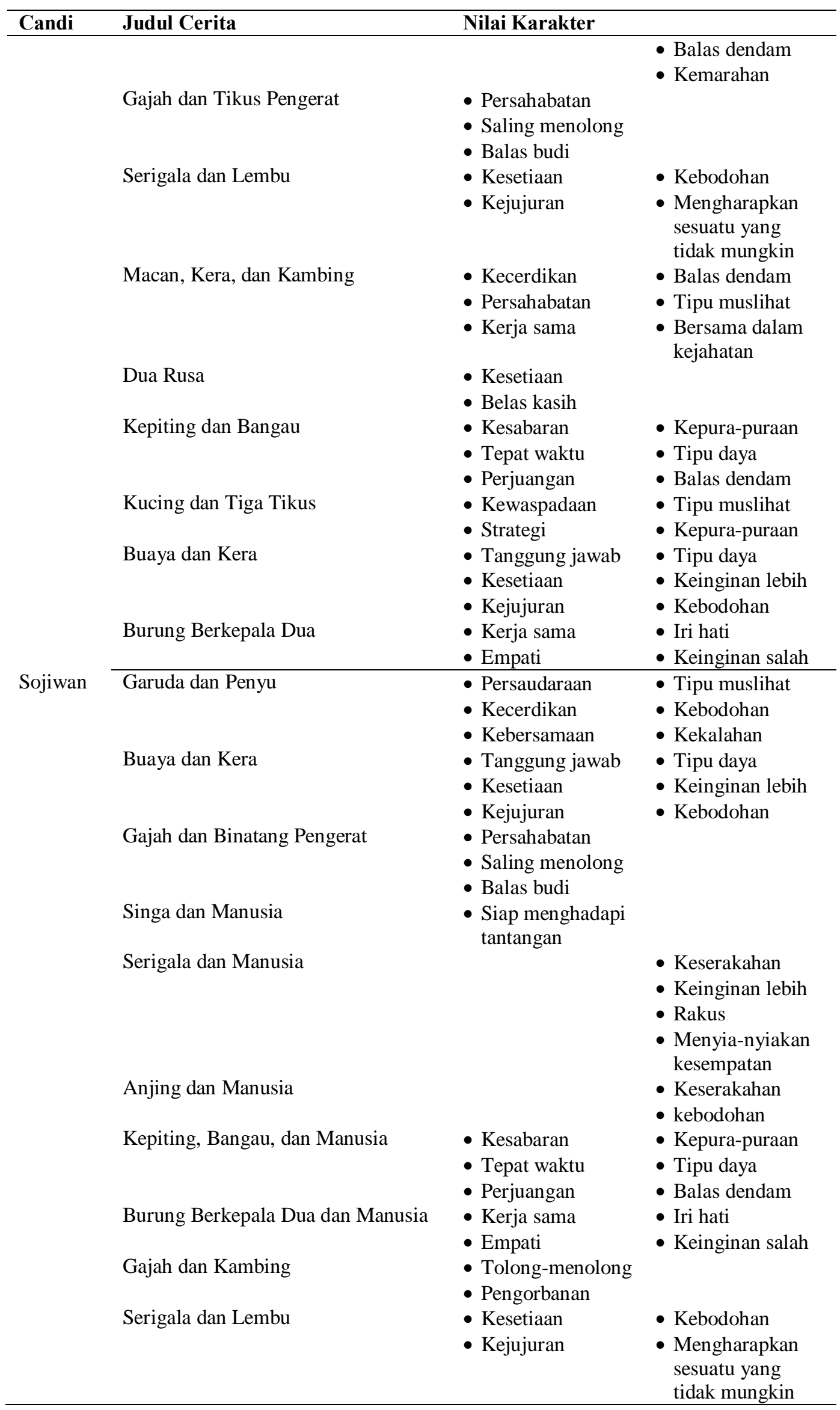


Tabel 2

Perbandingan Analisis Relief Candi Mendut dan Candi Sojiwan

\begin{tabular}{|c|c|c|c|c|}
\hline Analisis Relief & Candi Mendut & Candi Sojiwan & Persamaan & Perbedaan \\
\hline Naratif & $\begin{array}{l}\text { - Potongan } \\
\text { cerita, } \\
\text { monoscenic } \\
\text { narratives, } \\
\text { continuous } \\
\text { narratives }\end{array}$ & $\begin{array}{l}\text { - Potongan cerita, } \\
\text { monoscenic } \\
\text { narratives } \\
\text { - Muncul tokoh } \\
\text { lain, manusia } \\
\text { dengan inti } \\
\text { cerita } \\
\end{array}$ & $\begin{array}{l}\text { - Candi Mendut } \\
\text { dan Candi } \\
\text { Sojiwan } \\
\text { sebagian besar } \\
\text { berupa } \\
\text { monoscenic } \\
\text { narratives } \\
\end{array}$ & $\begin{array}{l}\text { - Ada satu } \\
\text { relief di } \\
\text { Candi } \\
\text { Mendut } \\
\text { merupakan } \\
\text { continuous } \\
\text { narratives } \\
\end{array}$ \\
\hline Bentuk & 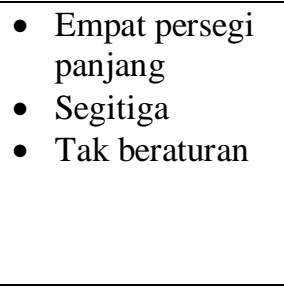 & $\begin{array}{l}\text { - Empat persegi } \\
\text { panjang }\end{array}$ & $\begin{array}{l}\text { - Bentuk empat } \\
\text { persegi panjang } \\
\text { - Dipisahkan } \\
\text { sekat antarpanil }\end{array}$ & $\begin{array}{l}\text { Di Candi } \\
\text { Mendut ada } \\
\text { relief } \\
\text { berbentuk } \\
\text { segitiga dan } \\
\text { tak } \\
\text { beraturan } \\
\end{array}$ \\
\hline \multicolumn{5}{|l|}{ Morfologi } \\
\hline Figur & $\begin{array}{l}\text { - Ular, luwak, } \\
\text { burung beo, } \\
\text { penyu, bangau, } \\
\text { manusia, } \\
\text { kerbau, kera, } \\
\text { kepiting, ular, } \\
\text { orang tua, rusa, } \\
\text { singa, manusia } \\
\text { terbang, gajah, } \\
\text { tikus pengerat, } \\
\text { serigala, } \\
\text { lembu, } \\
\text { kambing, } \\
\text { macan, kucing, } \\
\text { tiga tikus, } \\
\text { buaya, burung } \\
\text { berkepala dua }\end{array}$ & $\begin{array}{l}\text { - Garuda, penyu, } \\
\text { kera, buaya, } \\
\text { gajah, singa, } \\
\text { brahmana, } \\
\text { serigala, } \\
\text { manusia biasa } \\
\text { tua, anjing, } \\
\text { manusia biasa } \\
\text { muda, bangau, } \\
\text { kepiting, } \\
\text { pertapa, burung } \\
\text { berkepala dua, } \\
\text { manusia } \\
\text { berhiasan } \\
\text { gelang, } \\
\text { kambing, } \\
\text { anjing, lembu }\end{array}$ & - Naturalis & $\begin{array}{l}\text { - Di Candi } \\
\text { Sojiwan } \\
\text { ada yang } \\
\text { tidak } \\
\text { naturalis: } \\
\text { garuda, } \\
\text { kinnara, } \\
\text { manusia } \\
\text { berkepala } \\
\text { kera }\end{array}$ \\
\hline Pakaian & $\begin{array}{l}\text { Kalung, hiasan } \\
\text { leher, anting, } \\
\text { kain, perhiasan } \\
\text { lengan, gelang, } \\
\text { kalung pertapa, } \\
\text { rambut ukel, } \\
\text { mahkota, } \\
\text { sabuk, ikat } \\
\text { kepala }\end{array}$ & $\begin{array}{l}\text { Kalung garuda, } \\
\text { kain, rambut } \\
\text { ukel, pakaian } \\
\text { sederhana } \\
\text { manusia tua, } \\
\text { pakaian } \\
\text { sederhana } \\
\text { manusia muda, } \\
\text { pakaian biasa, } \\
\text { kain panjang } \\
\text { bagian depan }\end{array}$ & & \\
\hline Perhiasan & $\begin{array}{l}\text { - Perhiasan } \\
\text { lengan, gelang, } \\
\text { kalung pertapa, } \\
\text { rambut ukel, } \\
\text { mahkota, } \\
\text { sabuk, ikat } \\
\text { kepala }\end{array}$ & $\begin{array}{l}\text { - Gelang kaki } \\
\text { dan kalung } \\
\text { garuda, gelang } \\
\text { lengan }\end{array}$ & & \\
\hline Atribut & - Tombak, panah, & - Payung & & \\
\hline
\end{tabular}




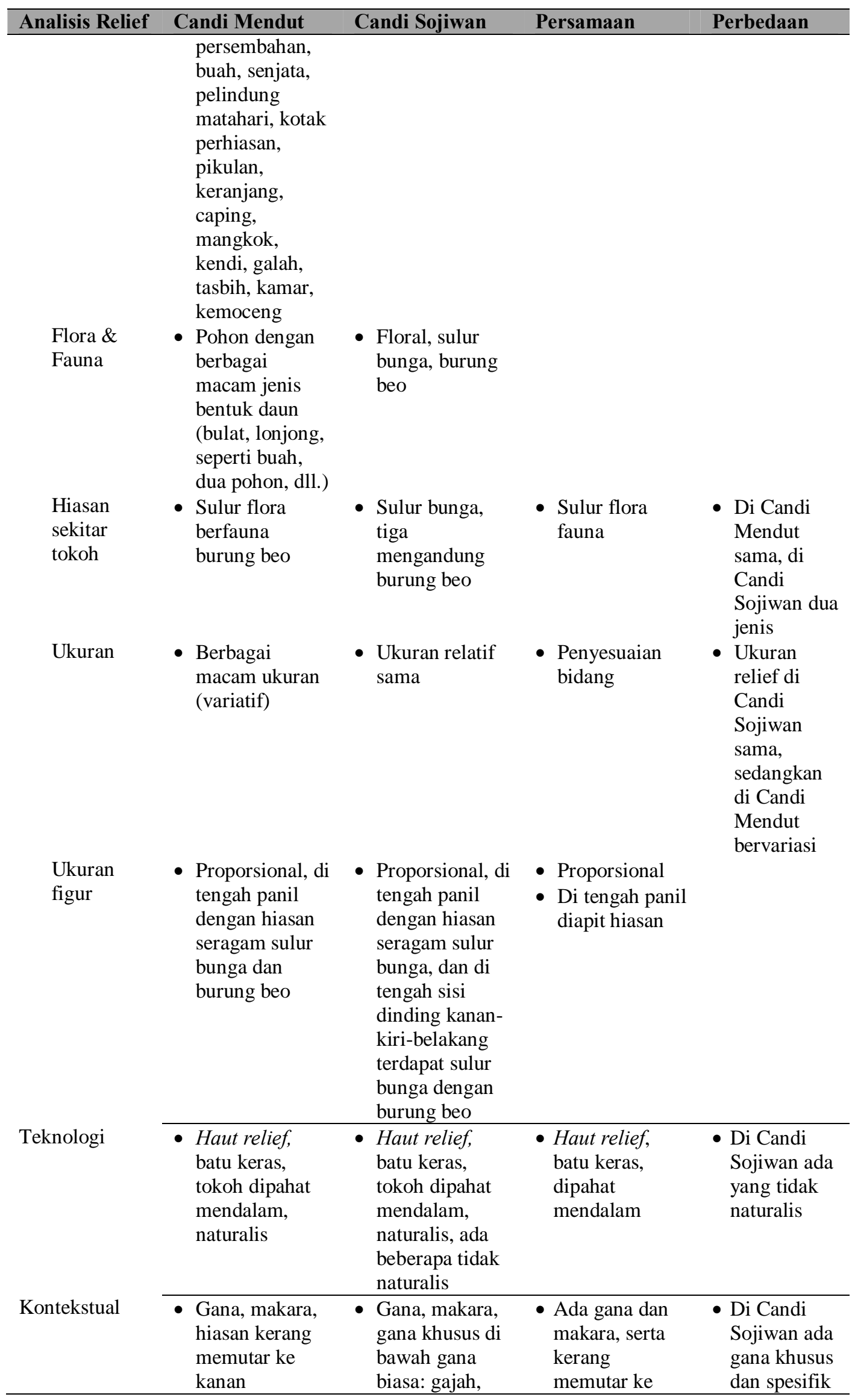




\begin{tabular}{lcccc}
\hline Analisis Relief & Candi Mendut & Candi Sojiwan & Persamaan & Perbedaan \\
\hline & & singa, manusia & kanan & - Ada kinnara \\
& menunggang & & pada Candi \\
& & singa, hiasan & & \\
& kerang & & \\
& memutar ke & & \\
& kanan & & \\
& &
\end{tabular}

Nilai-nilai karakter yang terkandung dalam cerita bertema pañcatantra di Candi Mendut dan Candi Sojiwan terbagi menjadi dua kelompok yaitu positif dan negatif. Nilai-nilai karakter ini diambil dari pemaknaan terhadap jalannya cerita pada masing-masing relief yang terpahat pada kedua candi. Nilai positif merupakan sikap luhur yang dimiliki tokoh cerita yang harus dilakukan, diperjuangkan secara konsisten, dan dikembangkan dalam diri seseorang. Sebaliknya, nilai negatif merupakan sikap-sikap buruk yang harus dihindari, dipadamkan, dan selayaknya tak dilakukan oleh seseorang dalam konteks sosialnya. Nilai-nilai karakter diperoleh sebagai interpretasi atas objek dan tandatanda khusus yang terdapat pada panil-panil relief cerita bertema pañcatantra di Candi Mendut dan Candi Sojiwan. Objek berupa relief cerita bertema pañcatantra ditemukan di kedua candi, berasal dari kisah-kisah dari India yang menyebar ke seluruh penjuru dunia. Objek tersebut memiliki tanda-tanda khusus yang dikenali sebagai cerita bertema pañcatantra yang mengandung nilai-nilai kehidupan untuk mengembangkan karakter.

Nilai-nilai karakter positif yang ditemukan dalam cerita bertema pañcatantra di Candi Mendut dan Candi Sojiwan yaitu pengorbanan, pertolongan, kebersamaan, suka cita, usaha keras, kerja bertahap, belas kasih, kebijaksanaan, persahabatan, saling menolong, persaudaraan, kecerdikan, berterima kasih, pemahaman sebab akibat, kesetiaan, kejujuran, kerja sama, kesabaran, tepat waktu, perjuangan, kewaspadaan, empati, dan siap menghadapi tantangan. Nilainilai karakter negatif yang ditemukan yaitu permusuhan, tipu daya, balas dendam, lupa diri, kesombongan, keras kepala, serakah, rakus, rencana jahat, pembunuhan, tipu muslihat, kebodohan, kekalahan, suka mengejek, kemarahan, mengharapkan sesuatu yang tidak mungkin, bersama dalam kejahatan, kepura-puraan, keinginan lebih, iri hati, keinginan salah, dan menyia-nyiakan kesempatan. Nilai positif dan negatif selalu menjadi dualisme yang ada pada situasi sosial masyarakat. 
Keduanya menjadi ciri khas kehidupan manusia dalam segala bentuk konteks sosial sejak dahulu hingga sekarang. Penggunaan cerita bertema pañcatantra untuk menunjukkan kompleksitas sosial dalam hal keterkaitan antarmanusia relevan hingga zaman sekarang dan yang akan datang.

Nilai-nilai karakter yang terkandung dalam cerita bertema pañcatantra di Candi Mendut dan Candi Sojiwan memiliki keselarasan dengan konsep kebajikan luhur (pāramitā) dalam ajaran agama Buddha, yaitu dāna (kemurahan hati), sīla (kebajikan, moralitas), nekkhamma (melepaskan keduniawian, kerelaan), pañ̃̄a (kebijaksanaan), viriya (tekun, semangat, usaha), khanti (kesabaran, toleransi, penerimaan, daya tahan), sacca (kebenaran, kejujuran), adhițthāna (tekad, resolusi), mettā (cinta kasih), dan upekkhā (ketenangseimbangan). Keterkaitan di antara keduanya dapat dilukiskan pada gambar 6 berikut ini.

\begin{tabular}{|c|c|c|c|c|}
\hline Nilai Positif & & Pāramitā & & Nilai Negatif \\
\hline $\begin{array}{l}\text { Pertolongan } \\
\text { Berterima kasih } \\
\text { Empati }\end{array}$ & 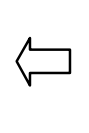 & Dāna & $\Rightarrow$ & $\begin{array}{r}\text { Serakah } \\
\text { Rakus } \\
\text { Keinginan lebih }\end{array}$ \\
\hline Balas budi & 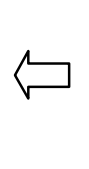 & Sīla & $\Rightarrow$ & $\begin{array}{r}\text { Balas dendam } \\
\text { Pembunuhan } \\
\text { Tipu muslihat } \\
\text { Suka mengejek }\end{array}$ \\
\hline $\begin{array}{l}\text { Tanggung jawab } \\
\text { Pengorbanan }\end{array}$ & 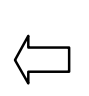 & Nekkhamma & $\Rightarrow$ & Kepura-puraan \\
\hline $\begin{array}{l}\text { Strategi } \\
\text { Kebijaksanaan } \\
\text { Pemahaman sebab akibat }\end{array}$ & 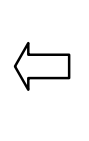 & Pañ̄̃ā & $\Rightarrow$ & $\begin{array}{r}\text { Kesombongan } \\
\text { Kebodohan }\end{array}$ \\
\hline $\begin{array}{l}\text { Kecerdikan } \\
\text { Kerja sama }\end{array}$ & $\forall$ & Viriya & $\Rightarrow$ & Kekalahan \\
\hline $\begin{array}{l}\text { Kerja bertahap } \\
\text { Kesetiaan } \\
\text { Kesabaran }\end{array}$ & 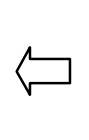 & Khanti & $\Rightarrow$ & $\begin{array}{r}\text { Mengharapkan sesuatu } \\
\text { yang tidak mungkin }\end{array}$ \\
\hline Kejujuran & 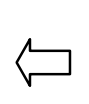 & Sacca & $\Rightarrow$ & $\begin{array}{r}\text { Kemarahan } \\
\text { Keinginan salah }\end{array}$ \\
\hline $\begin{array}{l}\text { Kebersamaan } \\
\text { Usaha keras } \\
\text { Tepat waktu } \\
\text { Siap menghadapi tantangan } \\
\text { Perjuangan }\end{array}$ & $b$ & Adhițthāna & $\Rightarrow$ & $\begin{array}{r}\text { Keras kepala } \\
\text { Menyia-nyiakan kesempatan }\end{array}$ \\
\hline $\begin{array}{l}\text { Belas kasih } \\
\text { Persahabatan } \\
\text { Persaudaraan }\end{array}$ & $\Leftrightarrow$ & Mettā & $\Rightarrow$ & $\begin{array}{r}\text { Permusuhan } \\
\text { Rencana jahat } \\
\text { Bersama dalam kejahatan }\end{array}$ \\
\hline
\end{tabular}




\begin{tabular}{|c|c|c|c|c|}
\hline Saling & & & & \\
\hline $\begin{array}{l}\text { Suka cita } \\
\text { Kewaspadaan }\end{array}$ & 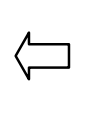 & Upekkhā & $\Rightarrow$ & $\begin{array}{r}\text { Tipu daya } \\
\text { Lupa diri } \\
\text { Iri hati }\end{array}$ \\
\hline Nilai Positif & & Pāramitāa & & Nilai Negatif \\
\hline
\end{tabular}

Gambar 1. Bagan Keterkaitan antara Nilai-Nilai Karakter Cerita Bertema Pañcatantra dengan Pāramitā

Kebajikan dāna (kemurahan hati) merupakan perbuatan yang mudah dilakukan oleh seseorang tanpa harus memiliki modal materi. Orang yang bermurah hati akan senang memberikan pertolongan kepada orang lain, baik donasi berupa barang, perlengkapan, uang, kebutuhan fisik, maupun nonmateri berupa sharing knowledge, nasihat, dan berbagai bentuk kepedulian lainnya. Hal ini dilakukan dengan motivasi meringankan beban orang lain dan sebagai wujud empati atas derita lingkungan sekitar. Pada konteks sosial, kemurahan hati dilakukan jika ada pihak lain yang perlu diberi bantuan atau sarana mewujudkan tindakan dāna. Dengan demikian, perbuatan dāna menjadi sempurna jika pihak lain menerima kebaikan yang diberikan oleh seseorang. Baik pemberi maupun penerima, keduanya terlibat dalam proses tindakan perbuatan bermurah hati berlangsung. Ucapan terima kasih dan rasa syukur menjadi ungkapan yang rasional atas kondisi tersebut. Pemberi mengucapkan terima kasih karena mendapatkan kesempatan berbuat baik, sedangkan penerima mengungkapkannya sebagai spontanitas atas ringannya beban yang dirasakan. Kemurahan hati tidak akan dimiliki jika di dalam diri seseorang terdapat sifat serakah, rakus, dan keinginan-keinginan berlebihan untuk memuaskan diri sendiri.

Sìla (kebajikan, moralitas) merupakan karakter luhur yang dapat dilaksanakan seseorang sebagai bentuk pengendalian diri agar dirinya terbebas dari kejahatan dan membawa dampak pada kehidupan sosial yang menjadi harmonis. Hubungan antarorang akan menjadi baik jika di antaranya saling menjaga hak dan kewajiban demi terciptanya stabilitas sosial. Dengan kata lain, perbuatan-perbuatan baik dilakukan seseorang atas dasar sebuah kewajiban untuk memenuhi hak orang lain. Jika keserasian antara hak dan kewajiban menjadi motivasi seseorang melakukan perbuatan, maka hubungan tersebut menjadi sarana 
balas budi atas kebaikan-kebaikan yang telah dikerjakan. Misalnya, seseorang yang mengendalikan diri dari perbuatan membunuh atau menyakiti makhluk lain, maka kesempatan orang lain untuk hidup terbuka lebar yang bisa jadi digunakan sebagai sarana untuk menyempurnakan kebaikan-kebaikan lainnya. Pembunuhan dapat berawal dari hal sepele saling mengejek antarteman sehingga memunculkan pertengkaran, tawuran, dan saling serang, serta diwarnai berbagai tipu muslihat hingga berujung saling balas dendam antargenerasi. Pengendalian diri sebagai unsur utama dalam pelaksanaan sīla akan menjaga suatu perbuatan buruk tidak muncul dan berdampak panjang. Secara otomatis, keseimbangan antara hak dan kewajiban anggota masyarakat akan serasi dan selaras.

Kebajikan nekkhamma (melepaskan keduniawian, kerelaan) memerlukan tanggung jawab dan pengorbanan besar dalam mewujudkannya. Seseorang yang memiliki sifat merelakan akan dengan mudah menerima segala macam kondisi dunia dan lingkungannya. Orang yang mudah merelakan memiliki tanggung jawab terhadap pihak lain, bahkan sering berkorban tanpa memikirkan kesenangan diri sendiri. Tanggung jawab merupakan bentuk integritas yang diperlukan untuk menumbuhkan kepercayaan seseorang dalam hubungan sosial agar menghasilkan masyarakat yang saling menghargai sesuai peran masingmasing. Peran seseorang di masyarakat ada kalanya dilaksanakan dengan penuh pengorbanan sesuai kapasitas, kemampuan, dan kesempatan yang ada, bahkan melebihinya. Pengorbanan dan kerelaan menjadi indikator kepedulian peran seseorang atas kepentingan bersama di masyarakat. Peran ini dilaksanakan penuh dedikasi tanpa harus berpura-pura menjadi diri orang lain. Atribut yang dikenakan seseorang mencerminkan peran dan tugas pekerjaan yang menjadi tanggung jawabnya. Jika ada seseorang yang berpura-pura memakai atribut yang dapat menipu orang lain, maka seiring berjalannya waktu tipu daya tersebut akan diketahui masyarakat sehingga secara otomatis orang tersebut akan mendapatkan hukuman sosial.

Kebajikan pañ̃̄a (kebijaksanaan) merupakan hasil dari memahami pengetahuan secara teoretis dan praktis yang didukung dengan landasan moral dan perenungan mendalam. Pemahaman mengenai sebab dan akibat menjadi ciri seseorang yang telah memiliki kebijaksanaan. Orang yang bijaksana mampu 
membedakan suatu perbuatan ke dalam kategori baik atau buruk. Perbuatan baik akan menghasilkan kebahagiaan, sebaliknya, perbuatan buruk akan menghasilkan penderitaan. Hasil proses pemahaman dan perenungan berupa kebijaksanaan diperoleh dengan menggunakan strategi, metode, pendekatan, media, dan evaluasi yang sesuai. Pemahaman dan perenungan ini untuk menghindari kebodohan dan kepicikan batin yang justru akan membelenggu diri seseorang. Kebodohan dan kepicikan akan membawa seseorang pada kesombongan, pembandingan, dan merasa unggul di atas orang lain. Orang yang bijaksana tidak akan membawa dirinya dan orang lain ke dalam tindakan-tindakan bodoh yang justru menjerumuskannya pada perilaku-perilaku irasional.

Kebajikan viriya (tekun, semangat, usaha) disempurnakan melalui konsistensi, perjuangan, dan dedikasi dalam melakukan tindakan apapun yang didasari keinginan memperbarui keadaan untuk menjadi lebih baik. Usaha yang tekun akan menentukan hasil yang dapat memberi kontribusi pada perubahan kehidupan seseorang. Orang yang memiliki viriya akan bekerja dengan gigih, tidak menyerah, tekun, dan berusaha menghasilkan karya terbaik yang bisa dilakukan. Hal ini membutuhkan kepandaian, kecerdikan, dan pengetahuan dalam menyusun rencana, melaksanakan, maupun mengevaluasinya. Perencanaan yang matang dengan penuh pertimbangan dan strategi pelaksanaannya dibutuhkan kerja sama dengan berbagai pihak agar muncul kolaborasi sosial yang saling mendukung satu sama lain. Kerja sama yang baik akan menumbuhkan kekuatan sinergis untuk mencapai hasil optimal sebagai indikator keberhasilan suatu proses. Keberhasilan yang diraih bersama merupakan kemenangan semua pihak yang memberi rasa puas sebagai antisipasi kekalahan.

Kebajikan khanti (kesabaran, toleransi, penerimaan, daya tahan) memberi kekuatan pada seseorang dalam menghadapi kehidupan yang dinamis. Kehidupan yang terus berubah harus diantisipasi dengan kesabaran, daya tahan, daya juang, penerimaan melalui kerja yang tekun, ulet, dan bertahap. Perubahan yang baik perlu disikapi dengan mawas diri dan tanpa kesombongan sebagai wujud toleransi kepada pihak-pihak yang tidak mendapatkan kesempatan yang sama. Perubahan yang buruk hendaknya digunakan sebagai kesempatan untuk meneguhkan kembali tekad semula dan dihadapi dengan penuh kesabaran dan daya tahan. 
Kekuatan khanti akan mendukung penyempurnaan kebajikan-kebajikan lain tanpa menyerah pada keadaan, bahkan kondisi tersulit sekalipun. Khanti yang teguh akan mengukur kemampuan diri dalam mengharapkan sesuatu yang tidak mungkin. Dengan kata lain, kesabaran dan daya tahan seseorang hendaknya disertai dengan perhitungan matang dan daya nalar yang mengukur kemampuan diri untuk mencapainya.

Sacca (kebenaran, kejujuran) menjadi ciri seseorang yang teguh dalam pendirian untuk menyampaikan kebenaran. Kebenaran harus dikatakan dengan jujur walaupun menyakitkan. Kejujuran mencerminkan kebulatan tekad seseorang dalam menjaga kebenaran tersampaikan secara objektif. Objektivitas suatu persoalan atau fenomena yang disampaikan menjadi indikasi integritas seseorang sebagai makhluk sosial. Kejujuran selalu berseberangan dengan kebohongan dan manipulasi yang dapat menyebabkan kemarahan. Berbagai bentuk kepalsuan, kebohongan, manipulasi maupun kecurangan yang dilakukan penguasa akan menimbulkan gejolak kemarahan publik. Hal ini akan berdampak besar pada penyelenggaraan dan stabilitas negara secara keseluruhan. Kebohongan, manipulasi, dan kecurangan didasari atas keinginan salah yang cenderung dilakukan untuk mencari keuntungan diri sendiri.

Adhițthāna (tekad, resolusi) merupakan kebulatan tekad sebagai wujud kemauan kuat yang dimiliki seseorang untuk mengupayakan niat dan resolusi agar terwujud hasil baik. Proses mewujudkan tekad ini diperlukan usaha keras, perjuangan, dan siap menghadapi tantangan agar menghasilkan pencapaian sesuai keinginan dan tepat waktu. Orang yang memiliki adhițthāna akan berusaha keras dan konsisten pada jalan yang sedang ditempuhnya. Bagi pemilik sikap adhițthāna ini, kegagalan akan menjadi tantangan yang siap untuk dihadapi sebagai kesempatan untuk berusaha lebih keras lagi. Suatu niat yang diperjuangkan akan memiliki dampak, baik bagi diri sendiri maupun orang lain. Dampak ini meneguhkan niat lainnya untuk segera diperjuangkan kembali. Namun demikian, dalam mengusahakan suatu niat baik harus menghindari sifat keras kepala semaunya sendiri tanpa mempertimbangkan pihak lain.

Kebajikan mettā (cinta kasih) merupakan kemauan baik yang didasari cinta kasih, persahabatan, dan persaudaraan untuk meringankan beban orang lain. 
Kesempurnaan mettā diwujudkan dalam bentuk belas kasih dan memberikan pertolongan pada pihak lain yang dipandang perlu diberi bantuan. Orang yang memiliki mettā akan bebas dari rencana jahat, rasa permusuhan, maupun bekerja sama dalam kejahatan. Hal ini dikarenakan sifat mettā yang didasari atas kebahagiaan pihak lain sehingga suasana persahabatan dan persaudaraan dijadikan sebagai sarana penyempurnaannya. Mettā dilakukan secara bertahap mulai dari diri sendiri, keluarga, lingkungan terdekat, komunitas, hingga semua makhluk tanpa batas secara universal.

Upekkhā (ketenangseimbangan) merujuk pada sifat batin yang seimbang karena pemahaman mendalam yang diperoleh dari pikiran yang tenang, bahkan dalam situasi sulit. Kewaspadaan dan eling-waspada menjadi ciri orang yang memiliki kebajikan upekkhā. Sikap batin upekkhā bukanlah hasil yang dipaksakan, tetapi dilakukan melalui aktivitas keseharian yang penuh suka cita. Orang yang memiliki upekkhā tidak mungkin memiliki usaha tipu daya, lupa diri, dan iri hati yang justru akan memperkeruh batinnya. Upekkhā sebagai kondisi seseorang yang batinnya tenang dapat dicapai dengan praktik meditasi dan hidup berkesadaran.

Pelaksanaan nilai-nilai kebajikan (pāramitāa) tidak dilakukan satu per satu secara berurutan, tetapi saling mendukung satu sama lain. Misalnya, seseorang yang memiliki adhițthāna ber-dāna dilakukan untuk mendukung nekkhamma dan sīla yang dijalankannya dengan penuh viriya, khanti, dan sacca atas dasar mettā dan pañ̃̄a dengan penuh upekkhā.

\section{KESIMPULAN DAN SARAN}

Penelitian ini memberikan kesimpulan, yaitu: (a) relief fabel yang dapat diidentifikasi memuat tema cerita pañcatantra pada Candi Mendut terdapat pada dinding pipi tangga masuk dan badan candi bagian dalam selasar sejumlah enam belas, sedangkan pada Candi Sojiwan terdapat pada lingkar badan candi berjumlah sepuluh; di mana cerita sama yang terpahat pada Candi Mendut dan Candi Sojiwan yaitu ñGaruda dan Penyuò, ñBuaya dan Keraò, ñGajah dan Tikus Pengeratò, ñKepiting dan Bangauò, ñBurung Berkepala Duaò, dan ñSerigala dan Lembuò; sedangkan cerita yang terdapat pada Candi Mendut tetapi tidak terdapat 
pada Candi Sojiwan yaitu ñUlar dan Luwakò, ñPenyu dan Angsaò, ñSeekor Keraò, ñBrahmana, Ular, dan Kepitingò, ñRusa, Macan, dan Keraò, ñUlar dan Manusia Terbangò, ñKera Pemarahò, ñMacan, Kera, dan Kambingò, ñDua Rusaò, dan ñKucing dan Tiga Tikusò; serta cerita yang hanya terdapat di Candi Sojiwan namun tidak terdapat pada Candi Mendut yaitu ñSinga dan Manusiaò, ñSerigala dan Manusiaò, ñAnjing dan Manusiaò, dan ñGajah dan Kambingò; (b) persamaan ornamen relief pañcatantra pada Candi Mendut dan Candi Sojiwan mengambil bentuk monoscenic narratives, namun terdapat pula bentuk continuous narratives pada Candi Mendut; di mana sebagian besar berbentuk empat persegi panjang, di samping ada juga bentuk segitiga dan tak beraturan pada Candi Mendut; dengan analisis morfologi figur yang dipahatkan sebagian besar naturalis, kecuali pada Candi Sojiwan ditemukan tidak naturalis berupa garuda, hiasan kerang, kinnara, dan manusia berkepala kera; morfologi pakaian dan perhiasan pada kedua candi memiliki persamaan yaitu penggunaan kain, gelang, kalung, gelang lengan, sabuk, ikat kepala, mahkota, rambut ukel, pakaian yang menunjukkan peran pada figur manusia; dengan atribut yang ada di sekitar tokoh sentral yaitu panah, galah, persembahan, buah, payung, senjata, kotak perhiasan, pikulan, keranjang, caping, mangkok, kendi, tasbih, kemoceng; morfologi hiasan di sekitar tokoh pada kedua candi didominasi oleh sulur floral berupa bunga berbentuk bulat berhias yang menampilkan banyak burung beo di Candi Mendut, sedangkan di Candi Sojiwan hanya ada tiga relief yang berhiaskan burung beo pada hiasan di sekitar tokohnya; morfologi berdasarkan ukuran relief pada Candi Mendut bervariasi sesuai dengan bidang yang ada, sedangkan pada Candi Sojiwan berukuran sama pada semua relief; di mana pada kedua candi memiliki ukuran figur tokoh sentral secara proporsional terletak pada tengah panil yang diapit oleh hiasan flora dan atau fauna; menurut analisis relief dari segi teknologi, kedua candi termasuk pada kategori haut relief (relief tinggi) dengan ciri terpahat pada batu keras, mendalam, dan lebih naturalis; namun demikian, pada Candi Sojiwan ditemukan garuda, kerang dengan arah putar ke kanan, kinnara, dan manusia berkepala kera yang tidak naturalis; pada analisis kontekstual, kedua candi berbeda atas ditemukannya gana unik dan spesifik berupa gajah, singa, dan manusia menunggang singa di Candi Sojiwan; di samping persamaannya yaitu terdapat makara dan gana dengan 
karakter yang sedikit berbeda; dan (c) nilai-nilai karakter cerita pañcatantra sebagai niti-shastra yang dapat dipakai sebagai the wise conduct of life pada Candi Mendut dan Candi Sojiwan yang bernilai positif, yaitu tanggung jawab, strategi, pengorbanan, pertolongan, kebersamaan, suka cita, usaha keras, kerja bertahap, belas kasih, balas budi, kebijaksanaan, persahabatan, saling menolong, persaudaraan, kecerdikan, berterima kasih, pemahaman sebab akibat, kesetiaan, kejujuran, kesabaran, tepat waktu, perjuangan, kewaspadaan, empati, dan siap menghadapi tantangan; namun demikian, terdapat nilai-nilai negatif yang muncul, di antaranya permusuhan, tipu daya, balas dendam, lupa diri, kesombongan, keras kepala, serakah, rakus, rencana jahat, pembunuhan, tipu muslihat, kebodohan, kekalahan, suka mengejek, kemarahan, mengharapkan sesuatu yang tidak mungkin, bersama dalam kejahatan, kepura-puraan, keinginan lebih, iri hati, keinginan salah, dan menyia-nyiakan kesempatan.

Peneliti memberikan saran kepada berbagai pihak sebagai berikut: (a) bagi penyelenggara pendidikan, baik formal, informal, maupun nonformal dapat menggunakan cerita-cerita bertema pañcatantra yang terdapat di Candi Mendut dan Candi Sojiwan untuk mengembangkan karakter bernilai positif dan menghindarkan peserta didik dari nilai-nilai negatif; (b) bagi pengambil kebijakan, baik lokal maupun nasional dapat memasukkan cerita-cerita bertema pañcatantra yang terdapat di Candi Mendut dan Candi Sojiwan sebagai contoh dalam sumber belajar yang digunakan; (c) bagi penggiat industri kreatif dapat menggunakan cerita-cerita bertema pañcatantra yang terdapat di Candi Mendut dan Candi Sojiwan sebagai sumber ide dan gagasan dalam menciptakan karyakarya inovatif yang mampu memberdayakan ekonomi masyarakat sekaligus mendukung upaya pemerintah dalam bidang human literacy; dan (d) bagi peneliti lain yang hendak melakukan penelitian serupa dapat lebih memperdalam kajian guna mendapatkan simpulan yang komprehensif.

\section{DAFTAR ACUAN}

Dédé Oetomo. 2013. Penelitian Kualitatif: Aliran \& Tema. Metode Penelitian Sosial: Berbagai Alternatif Pendekatan. Editor Bagong Suyanto \& Sutinah. Jakarta: Kencana. 
Dehejia, Vidya. 1997. Discourse in Early Buddhist Art: Visual Narratives of India. New Delhi: Munshiram Manoharlal.

Dewan Redaksi Pusat Penelitian dan Pengembangan Arkeologi Nasional. 2008. Metode Penelitian Arkeologi. Jakarta: Pusat Penelitian dan Pengembangan Arkeologi Nasional, Badan Pengembangan Sumber Daya Kebudayaan dan Pariwisata, Departemen Kebudayaan dan Pariwisata.

Djamal. 2015. Paradigma Penelitian Kualitatif. Yogyakarta: Pustaka Pelajar.

Kaelan. 1959. Petundjuk Tjandi: Mendut, Pawon, Barabudur. Jogjakarta: Djawatan Kebudajaan, Tjabang Bagian Bahasa.

Lailly Prihatiningtyas. 2017. Kraton Ratu Boko: A Javanese Site of Enigmatic Beauty. Yogyakarta: PT Taman Wisata Candi Borobudur, Prambanan, Ratu Boko.

Made Taro. 2015. Kisah-Kisah Tantri. Denpasar: Sanggar Kukuruyuk.

Mingun, Tipi İ̃kadhara, Sayadaw. 2009. Riwayat Agung Para Buddha: The Great Chronicle of Buddhas. Terjemahan Indra Anggara. Jakarta: GiriMangala Publications \& Ehipassiko Foundation.

Muchlas Samani \& Hariyanto. 2012. Konsep dan Model Pendidikan Karakter. Bandung: PT Remaja Rosdakarya.

Pai, Anant. 1981. Panchatantra: Crows and Owls and Other Stories. Mumbai: Padmini Mirchandani for India Book House.

Ryder, Arthur W. 1925. The Panchatantra of Vishnu Sharma: English Translation. Chicago: The University of Chicago Press.

Shivkumar. 2015. Stories From Panchatantra. New Delhi: Childrenô Book Trust.

Soeharsono. 1969. Petunjuk Singkat untuk Bangunan Sutji Barabudur. Jogjakarta: Penerbit Taman Siswa.

Sugiyono. 2007. Memahami Penelitian Kualitatif. Bandung: Penerbit Alfabeta. 